\title{
Use of circumferential tangential cryostat sections of the intestine in the diagnosis of Hirschsprung's disease
}

\author{
JOHN L. EMERY, ETHEL FINCH, AND JAMES LISTER \\ From the Departments of Pathology and Paediatric Surgery, Children's Hospital, Sheffield
}

SYNOPSIS Technical and staining methods are described for making tangential sections using a specially prepared chuck surface in a cryostat. The method gives a rapid definitive diagnosis of Hirschsprung's disease in children.

Since the recognition of a deformity in the intramural ganglionic plexus of the colon in Hirschsprung's disease (Whitehouse and Kernohan, 1948; Bodian, Stevens, and Ward, 1949), the definitive surgical treatment of Hirschsprung's disease has included the resection of part, or all, of the abnormally innervated bowel (Swenson and Bill, 1948; Duhamel, 1956; Soare, 1963).

Positive diagnosis of the condition can only be made from the histological examination of the intrinsic ganglionic plexuses which can be obtained either from the rectal biopsy or from a colon biopsy obtained at laparotomy.

Furthermore, since macroscopic examination of the colon does not give an accurate indication of the extent of the disease, most surgeons will demand reports on frozen sections during the definitive operation to confirm that no affected colon is left in continuity.

The pathologist, confronted with such specimens, can find his work either extremely simple or very difficult. If, in the first section of the piece of bowel supplied, a group of normal ganglion cells can be clearly seen, the pathologist is reasonably satisfied. It frequently occurs that no definite ganglion cells are obvious and the tissue is so distorted that the exact location of the section is not easily identifiable. The only satisfactory solution in such circumstances is to do serial sections and look at each one.

Other aspects of diagnosis sometimes cause difficulties. The distribution of ganglion cells is not uniform thoughout the gut, there being more ganglion cells located in the region of the longitudinal muscle striae than in the intervening tissues. Thus, it is usually better to take a transverse rather than a longitudinal section of the wall.

Received for publication 19 October 1966.
As part of a recent research project on the development of the ganglionic plexus of the rectum and anus (Finch, Emery, and Lister, 1967), we attempted to study the plexus by a variety of methods and, in particular, to dissect out the plexus as Gunn has done in animals (Gunn, 1951). This was difficult and time consuming so an alternative technique was sought to locate as large a mass of plexus as possible.

We have developed a method of cutting thick, cryostat sections in a direction parallel to the main muscle layers. This method gives a fine display of the intramural ganglionic plexus and one in which the ganglionic tissue can be examined as a full structure. This approach was used by Leaming and Cauna (1961) when studying the intramural plexus of the small bowel of the cat. As this method is applicable for diagnostic work, it is described here with the staining techniques that we have found most useful.

\section{MATERIAL AND METHOD}

A cryostat (Bright's with a Cambridge rocker) has been used at $-20^{\circ} \mathrm{C}$. and sections cut at $10 \mu$.

Chucks are prepared in the following way. Small slices of liver, approximately $1 \mathrm{~cm} . \times 1 \mathrm{~cm} . \times 5 \mathrm{~mm}$., are obtained from routine necropsies. These are frozen on to the end of the metal chucks with cardice. The chuck is orientated on the microtome so that the small marking hole is exactly at the top. The liver is cut down until the surface is completely smooth, i.e., so that the surface has the contour of the cut of the rocking microtome knife. Several chucks are prepared in this way and these are kept in the frozen state in the cyrostat cabinet.

The material is received direct from the operating theatre. If the specimen is a small biopsy, an attempt is made to extend it, while moist, on a piece of card. If the specimen is a full piece of bowel it is cut open and pinned out flat. 
Small areas of tissue, approximately $1 \mathrm{~cm}$. square, are cut out. These are then lightly pressed on to the cut surface of the frozen liver on the prepared cryostat chucks. Initially, we stretched the unfixed bowel over the surface of the liver but later found that it was only necessary to take the tissue and hold it flat against the surface of the cut frozen liver with the chuck kept cool in cardice. The cold liver makes the bowel wall freeze on to its surface. The intestine can be placed either mucosal surface or muscular surface against the liver. With very thin pieces of bowel, it is better to have the mucosal surface away from the liver to allow a greater distance for trimming before the intramuscular plexus is reached. The chuck is then orientated on the microtome in its original position so that the plane of cut of the knife is exactly parallel to the cut liver surface. Serial sections are cut right through the intestine at $10 \mu$ or $15 \mu$ and the sections are taken off on to numbered cover glasses.

In young infants, who form an increasing proportion of those studied, the whole thickness of the bowel is retained within 30 or so sections, whilst with children around the age of 2 years, 60 or 70 sections, or more, are required before Auerbach's plexus is reached.
In dealing with tissues for immediate diagnosis, the depth of the section in the tissue can be seen by looking at the unstained cover slip section under low-power. The general direction of the muscle bundles is obvious and Auerbach's plexus occurs in the sections where muscle bundles can be seen running at right angles. A quick stain in Solachrome cyanin and rinse in water is more reliable for location of plexus.

\section{STAINING METHODS}

Whilst haematoxylin and eosin give an adequate preparation, we find that acid solachrome cyanin gives both a quicker staining time and also greater differentiation between nerve cells and muscle cells. The cells of the intramural plexus stain distinctly blue compared with the pink muscle and the nerve plexus can be picked out easily.

METHOD FOR USE WITH SOLACHROME (Hyman and Poulding, 1961). Solachrome Cyanin R.S., 0.2 g., is dissolved in $0.5 \mathrm{ml}$. of concentrated hydrochloric acid. After effervescence has subsided the mixture is diluted with $95 \mathrm{ml}$. of distilled water and $5 \mathrm{ml}$. of $1 \%$ iron alum is added.

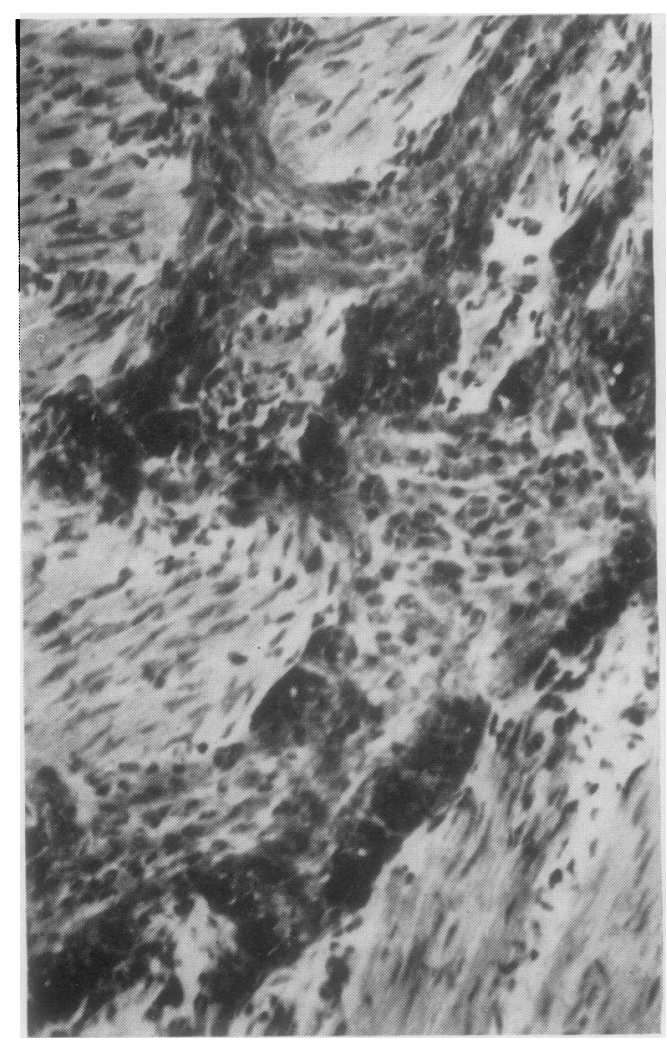

FIG. 1a.

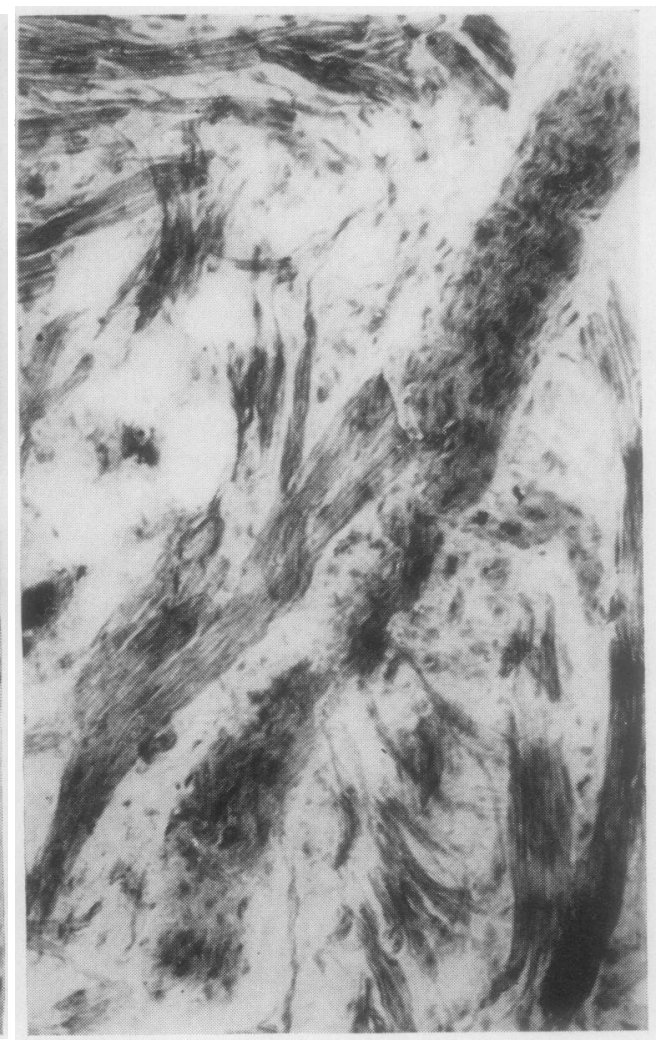

FIG. 1 b. sprung's disease, prepared as described in the text, and stained with Solachrome.

Fig. Ia is from the proximal part of the colon and Fig. Ib is from the spastic aganglionic area $(\times 160)$. 


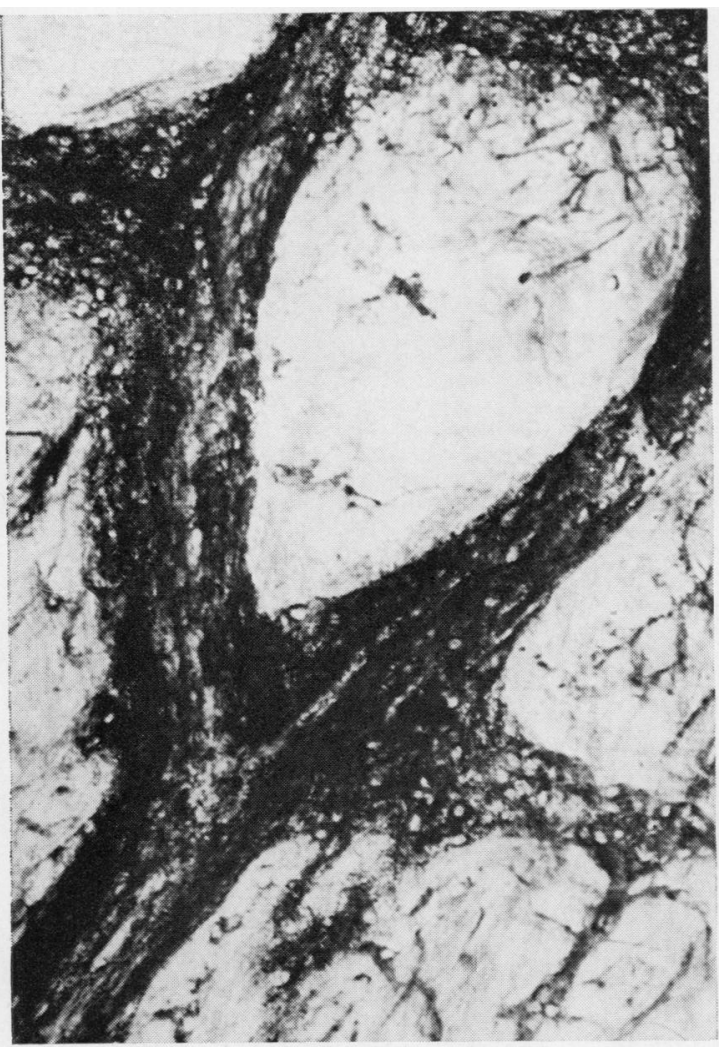

FIG. 2a.

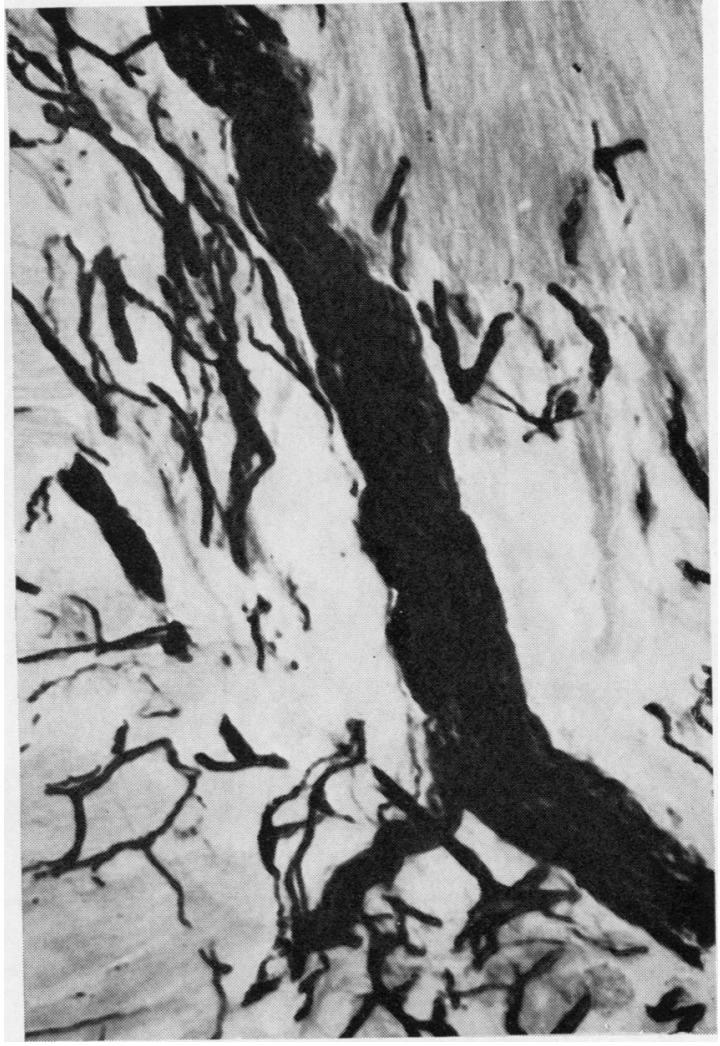

FIG. 2 b.

FIGS. $2 \mathrm{a}$ and $2 \mathrm{~b}$. These are photographs from sections taken in series from the same blocks as those shown in Figures $1 a$ and $1 b$, stained for acetylcholinesterase and photographed at the same magnification.

Note the rope-like nerves in the abnormal plexuses and the aborizing mass of staining tissue in the normal plexus in which the cell nuclei appear as small, clear spaces.

The section is immersed in this stain for $\frac{1}{2}$ to 1 minute, rinsed quickly in alkaline tap water and either examined directly, or after dehydration and mounting in picolite.

Photographs from the proximal normal end and the distal abnormal end of an operation specinien from a case of Hirschsprung's disease are shown stained by Solachrome in Figures 1a and b. As will be seen, these thick sections do not give very great intracellular detail, but immediately tell you whether there is a normal mass of ganglionic tissue or not.

A further staining technique which we find very useful in the confirmation of Hirschsprung's disease and which is done on the same cryostat sections, is an incubation technique for acetylcholinesterase.

ACETYLCHOLINESTERASE TECHNIQUE The method applied is a modification of that originally devised by Koelle and Friedenwald (1949), using acetylthiocholine iodide as substrate. This method depends upon the enzymic hydrolysis of the carboxylic acid ester of thiocholine sulphate in the presence of a cupric ion complex. This is followed by the precipitation of the liberated thiocholine sulphate as a copper mercaptide. This deposition of copper thiocholine is made conspicuous by treatment with dilute ammonium sulphide which produces a brown copper sulphide deposit (Holmstedt, 1957).

Details of the actual method, which is a modification of that described by Gomori (1952), are presented elsewhere (Finch, Emery, and Lister, 1967).

Using this technique, a very marked difference is immediately apparent between the normal and abnormal nervous tissue in cases of Hirschsprung's disease. The normal ganglionic plexus (Fig. 2a) consists of a conjoined mass of nerve cells in which the nuclei stand out as pale, unstained areas. The staining of the cell bodies is the most prominent part of the tissue. This contrasts very markedly with the appearance seen in the abnormal 'aganglionic' part of the bowel where, instead of a groundwork of nerve cells, there are large, deeply staining nerve trunks, forming a very conspicuous, coarse, irregular network (Fig. 2b).

\section{COMMENT}

The method of sectioning described here is, in our experience, best used on fresh tissue using a cryostat. 
A variety of modifications of preparing the tissue can be used. A small piece of fresh gut can be frozen directly on to the liver and sections cut immediately.

Alternatively, it is possible to stretch a length of bowel by pinning out on to cork or spreading out on thin card. The tissue is then quenched by plunging into liquid nitrogen. The whole specimen can then be stored in a polythene container in a deep freeze.

When serial sections are required, a small piece of flattened tissue is attached to the prepared 'liver' chuck as described. Sections obtained by this second technique are often not as good as those by the first method.

Leaming and Cauna (1961) used fixed tissue in their work on cats' intestines. They fixed the gut for three to six hours in $10 \%$ neutral formalin and this was followed by cutting frozen sections. We have not found this method as convenient or the sections obtained as good as when fresh tissue was cut.

This tangential method obviously takes longer to carry out than a longitudinal or transverse quick frozen section, but it gives a more definite answer to the question as to whether or not the intramural plexus is normal or abnormal at a particular site of the large bowel or rectum.

Photographs were taken by Mr. H. Coussins. The work was carried out under a grant from the Endowment Fund of the United Sheffield Hospitals.

\section{REFERENCES}

Bodian, M., Stevens, F. D., and Ward, B. C. H. (1949). Lancet, 1, 6. Duhamel, B. (1956). Presse Méd., 64, 2249.

Finch, E., Emery, J. L., and Lister, J. (1967). In Proceedings of a Symposium on Metabolic Diseases, Moyne Institute, Dublin. (To be published).

Gomori, G. (1952). Microscopic Histochemistry, p. 210. University of Chicago Press, Chicago.

Gunn, M. (1951). Quart. J. micr. Sci., 92, 55.

Holmstedt, B. (1957). Acta physiol. scand., 40, 322.

Hyman, J. M., and Poulding, R. H. (1961). J. med. Lab. Technol., 18, 107.

Koelle, G. B., and Friedenwald, J. S. (1949). Proc. Soc. exp. Biol. (N.Y.), 70, 617 .

Leaming, D. B., and Cauna, M. (1961). J. Anat. (Lond.), 95, 160.

Soare, F. (1963). Osped. Ital.-Chir., 8, 285.

Swenson, O., and Bill, A. H., Jr. (1948). Surgery, 24, 212.

Whitehouse, F. R., and Kernohan, J. W. (1948). Arch. intern. Med. 82, 75 .

\section{Reports and Bulletins prepared by the Association of Clinical Biochemists}

The following reports and bulletins are published by the Association of Clinical Biochemists. They may be obtained from Mr. J. T. Ireland, Biochemistry Laboratory, Alder Hey Children's Hospital, Liverpool, 12. The prices include postage, but airmail will be charged extra.

\section{SCIENTIFIC REPORTS}

1 Colorimeters with Flow Through Cells. A Critical Assessment of 4 Instruments. 1965. P. M. G. BROUGHTON and C. RILEY. 13s. 6d.

2 Colorimeters: A critical assessment of 5 commercial instruments. 1966. P. M. G. BROUGHTON, C. RILEY, J. G. H. COOK, P. G. SANDERS, and H. BRAUNSBERG. 15s.

\section{TECHNICAL BULLETINS}

2 A Report on the Enzyme Questionnaire Circulated by the Scientific Committee. December 1964. A. H. GOWENLOCK. 1s.

3 Non-recording Spectrophotometers for the Visible and Ultraviolet Ranges. A comparative table of instruments available in Great Britain. May 1965. A. H. GOWENLOCK, P. C. NICHOLAS, and J. H. WILKINSON. 1s. 6d.
4 Control Solutions for Clinical Biochemistry. June 1965. P. M. G. BROUGHTON and A. H. GOWENLOCK. 1s. 6 d.

5 Recording Spectrophotometers. A comparative list of low-priced instruments readily available in Britain. July 1965 . P. SEWELL. 2s. 6d.

6 A Guide to Automatic Pipettes. A list of more than 100 instruments compiled from manufacturers' literature. August 1965. P. M. G. BROUGHTON. 5s.

7 Variability Between Auto-Analyzer Modules. August 1965. B. E. NORTHAM. 1s. 6d.

8 Flame Photometers. A comparative list of 15 instruments readily available in Britain. June 1966. C. RILEY. 4s.

9 Determination of Urea by Auto-Analyser. November 1966. RUTH M. HASLAM. 2s. 6d.

10 Filter Fluorimeters. A comparative list of 14 instruments. March 1967. HANNELORE BRAUNSBERG. 5s. 